\title{
An Efficient Method for Regeneration of Stevia rebaudiana (Bertoni) in Egypt
}

\author{
Marwa. M. Ghallab and M. S. Saleh ${ }^{1}$
}

\begin{abstract}
Stevia rebaudiana Bertoni, a natural sweetener plant with zero calorie content, becomes an inevitable alternative to sugar especially with the over 346 million diabetic population across the world. The present experiments were conducted to standardize an in vitro culture technique of stevia rebaudiana to explore its potential for callus culture. Leaves explants were cultured on MS medium with specific concentration of growth regulators $(2,4-D, B A$, Kin and NAA). The results showed that, 1 . MS medium containing 1mg/l 2,4-dichlorophexoy acetic acid $(2,4-D)+0.5 \mathrm{mg} / \mathrm{l}$ Benzyl adenine(BA) was gave the best result of callusing. 2 . Higher regeneration of plants (32.6 plantlets/callus) was obtained by placing callus on MS medium with 5mg/l BA. 3. Highest rate of root formation $(56 \%)$ and rooting average (6.1) was recorded in MS medium with $1 \mathrm{mg} / \mathrm{I} \mathrm{IBA.}$
\end{abstract} callus.

Key words: stevia rebaudiana, in vitro, regeneration,

\section{INTRODUCTION}

Stevia rebaudiana Bertoni, is perennial herb belongs to the Asteraceace family. It is a natural sweetener plant known as "sweet weed","sweet leaf","sweet Herbs" and Honey leaf which is estimated to be 300 times sweeter than sugar (Chalapathi et al, 1997 and Liu and Li, 1995). Leaves of stevia are the source of diterpene glycosides,viz. stevioside and rebaudioside (yoshida,1986). stevioside is regenerated as a valuable natural sweetening agent because of its relatively good taste and chemical stability (Yamazaki and Flores, 1991 and Toyoda and Matsui, 1997). The Stevia plant was recently introduced to Egyptian agriculture in order to produce a natural sweetener than can cover some of the lack of sugar production in Egypt (Alaam, 2007).

Unfortunately seeds of stevia show a very low germination percentage. Propagation by seeds does not allow the production of homogeneous population, resulting in great variability in important features like sweetening levels and composition (Nakamura and Tamura,1985). In addition, vegetative propagation is limited by the lower number of individuals that can be obtained simultaneously from a single plant (Sakaguchi and Kan, 1982). Because of these difficulties; tissue culture is alternative for rapid mass propagation of stevia plants. Plant tissue culture technology may help to conserve rare and endangered medicine plants. Many important medicinal herbs have been successfully propagated in vitro either by organogenesis (Debnath et al.,2006) or by somatic embryogenesis.

Plant tissue culture or micropropagation cane be used for rapid propagation and conservation of such valuable and endangered plant species (Nalawade et al., 2002), which is difficult to propagate by conventional methods. This technique allows rapid multiplication, lack of seasonal restriction, provides sufficient number of plants in very short span of time, self incompatible inbred lines can be maintained. Micropropagation ensures the production of disease free, high yield and premium quality planting material for automation (Chawa.2000).

The present study was carried out to finding efficient protocol for in vitro accelerated mass multiplication of Stevia rebaudiana in Egypt.

\section{MATERIALS AND METHODS}

The present experiment was established in the tissue culture Laboratory and green house of Agricultural Research Station, Sabahia, Alexandria. Sugar Crop Research Institute, Ministry of Agriculture, Egypt.

In this study, the plants were grown in pots and maintained in green house. Leaf explants ranging in size from 1 to $1.2 \mathrm{~cm}$ were collected from young growing plants. After excision they were rinsed in running tap water for $20 \mathrm{~min}$. Then they were surface sterilized with $0.1 \%$ mercuric chloride for 15 min followed by rinsing them five times with distilled water inside the laminar air flow chamber. The explants were cut into small pieces ranging in size from 0.3 to $0.5 \mathrm{~cm}$. The explants were inoculated in MS medium (Murashig and Skoog, 1962) fortified with specific concentration of growth regulators (2, 4-D, BA, Kin and NAA). $\mathrm{pH}$ of the medium was adjusted to 5.8 with $0.1 \mathrm{~N}$ solution of $\mathrm{NaOH}$ or $0.8 \%$ agar was used for solidification of medium. The medium was autoclaved at $121 \mathrm{C}^{\circ}$ and $1.06 \mathrm{~kg} \mathrm{~cm}^{-2}$ for 20 minutes.

After inoculation, cultures were maintained at a temperature of $25 \pm 2$ in dark for callus induction. Sub cultures were done every 28 days interval. Various types of growth regulator viz.BA, Kn and NAA were added with MS medium either alone or in combination for better shoot formation (Table 2). After 30-35 days of culturing, the multiple shoots were separated into pieces and the separation at the base of multiple shoots and transferred to the same kind of medium to get a more

\footnotetext{
${ }^{1}$ Genetics and Breeding Department, Sugar Crop Research Institute, Sabahia Research Station

Received November 18, 2012, Accepted December 27, 2012.
} 
number of new shoots. For root initiation, regenerated multiple hoots were cut and individual shoot was placed in MS medium supplemented with different concentration of IBA, NAA or without adding of growth regulators.

\section{RESULTS AND DISCUSSION}

\section{1- Callus induction}

The results obtained from this part of study showed that, among all treatments, the highest rate of callus induction from leaf explants $(80 \%)$ and the highest rate of embryogenic callus $(80.6 \%)$ within 5.9 days of inoculation was observed on medium 1 (Figure 1) followed by medium 2 with $(60.4 \%)$ rate of callus induction and $(50.9 \%)$ rate of embryogenic callus within 7.2 days. while no significant effect was observed of media 3 and 4 (table 1 and figure 2).

These results are in agreement with those obtained by Amir et al. (2010) since they found that among all treatments, the highest rate of callus from leaf explants (96\%) within 11days of inoculation was observed on MS basal medium containing 3mg/l 2, 4-D. When the 2,4-D was used in combination with BA, increased and rate of callus and had been induction was noticed in nodal an intermodal explants as compared to 2,4-D
alone.Such results are in a harmony with those obtained by Kuntal et al. (2006) and Sairkar et al. (2009). Kuntal et al. (2006) showed that 2, 4-D at $1.0 \mathrm{mg} / \mathrm{l}$ and kinetin at $0.2 \mathrm{mg} / \mathrm{l}$ combination gave extensive initiation of callus. Sairkar et al. (2009) mentioned that 2mg/l 2, 4-D with $1.0 \mathrm{mg} / \mathrm{l}$ kinetin gave $88 \%$ callus induction (excellent growth).

Callus formation was observed when auxin 2, 4-D or NAA were used alone or supplemented with small amount of cytokinin(BA). There was wide range of variation in days for callus initiation response and percentage of callus formation. The genes affecting structure and type of plant development, may influence callus formation. This depicts the involvement of inheritance in callus growth (Turhan, 2004).

\section{2-Shoot multiplication}

For shoot formation in stevia rebaudiana, it can be noticed that, MS medium containing 5mg/l BAP provided a best result for shoot formation (75\%) where number of shoots per culture was observed to be 32.6 and average length of shoots per culture found to be $3.2 \mathrm{~cm}$ within 6.1 days (figure 3) followed by MS medium $+0.5 \mathrm{mg} / \mathrm{l} \mathrm{BA}$, while no significant effect was found with other media (Table2,figure4).
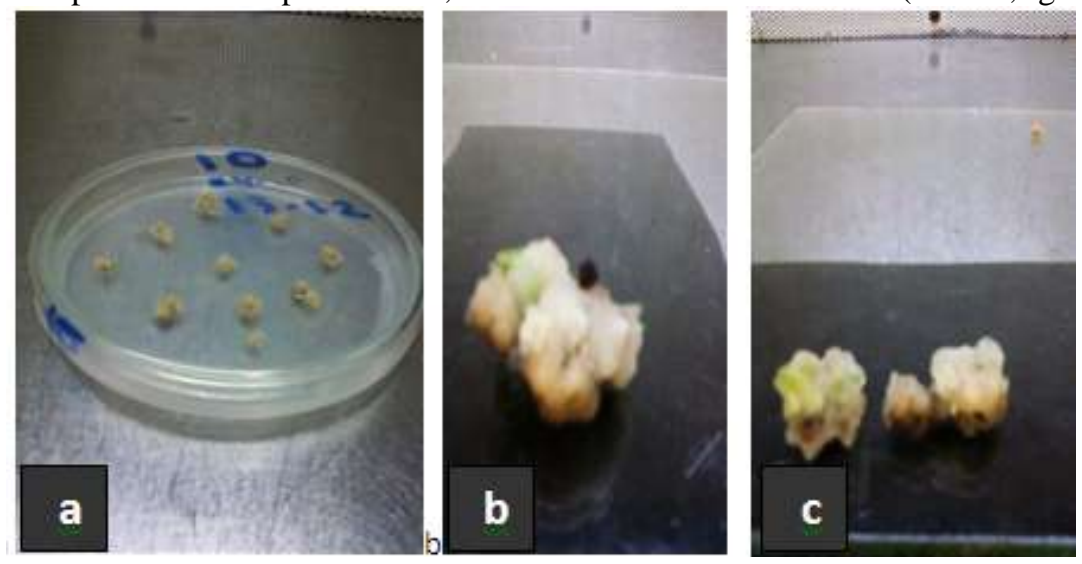

Figure 1. Callus formation was on 2,4-D $(1 \mathrm{mg} / \mathrm{l})+\mathrm{BA}(0.5 \mathrm{mg} / \mathrm{l})$ a) subculture of callus b) embryogenic callus c)embryogenic and non embryogenic callus

Table 1. Effect of different media on callus induction after four weeks

\begin{tabular}{lccc}
\hline Means & $\begin{array}{c}\text { Days for callus } \\
\text { initiation }\end{array}$ & $\begin{array}{c}\text { Rate of callus induction } \\
(\%)\end{array}$ & $\begin{array}{c}\text { Rate of embryogenic } \\
\text { callus }(\%)\end{array}$ \\
\hline $\begin{array}{l}\text { Medium1 } \\
(\mathrm{MS}+1 \mathrm{mg} / 12,4 \mathrm{D}+0.5 \mathrm{mg} / \mathrm{lBA})\end{array}$ & $5.9 \mathrm{a}$ & $80 \mathrm{c}$ & $80.6 \mathrm{~d}$ \\
\hline $\begin{array}{l}\text { Medium2 } \\
(\mathrm{MS}+2 \mathrm{mg} / 12,4-\mathrm{D}+1 \mathrm{mg} / \mathrm{lKin})\end{array}$ & $7.2 \mathrm{~b}$ & $60.4 \mathrm{~b}$ & $50.9 \mathrm{c}$ \\
\hline $\begin{array}{l}\text { Medium3 } \\
(\mathrm{MS}+3 \mathrm{mg} / \mathrm{l} 2,4-\mathrm{D})\end{array}$ & $6.3 \mathrm{ab}$ & $50.3 \mathrm{a}$ & $50 \mathrm{~b}$ \\
\hline $\begin{array}{l}\text { Medium4 } \\
(\mathrm{MS}+1 \mathrm{mg} / \mathrm{lBA}+2 \mathrm{mg} / \mathrm{lNAA})\end{array}$ & $6.5 \mathrm{ab}$ & $40.7 \mathrm{a}$ & $30.9 \mathrm{a}$ \\
\hline
\end{tabular}

Means followed by different letters in the same column differ significantly at $\mathrm{p}=0.05$ 


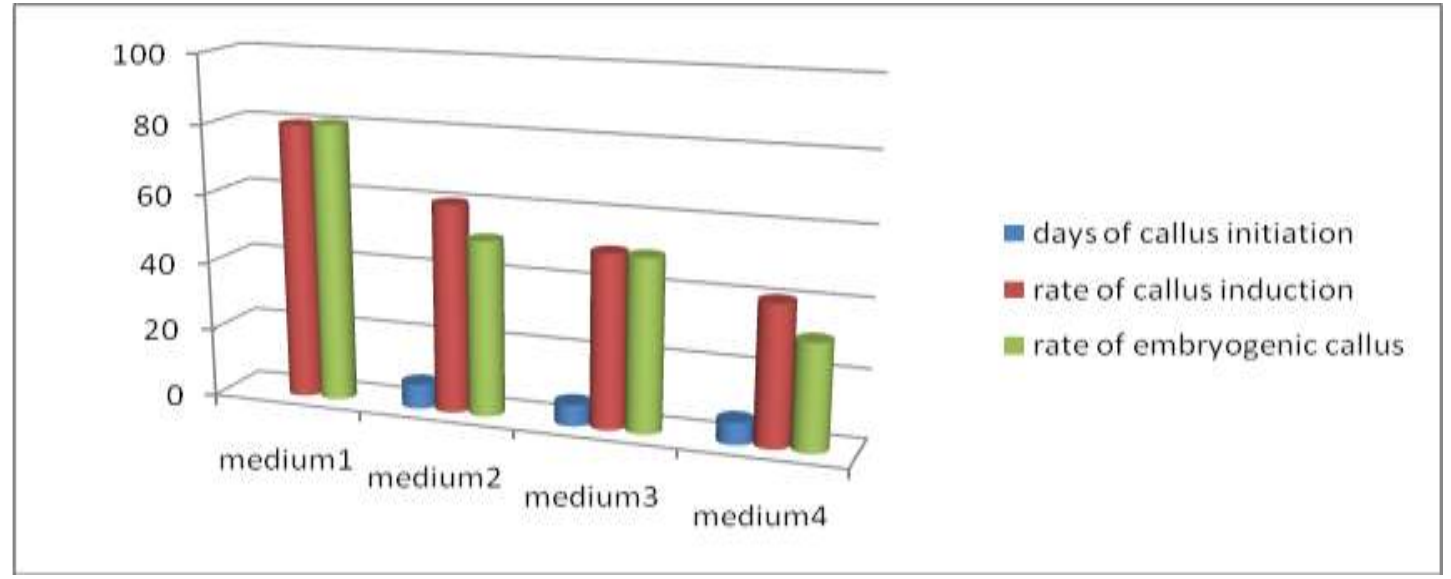

Figure 2. Effect of different media on callus induction and embryogenic callus
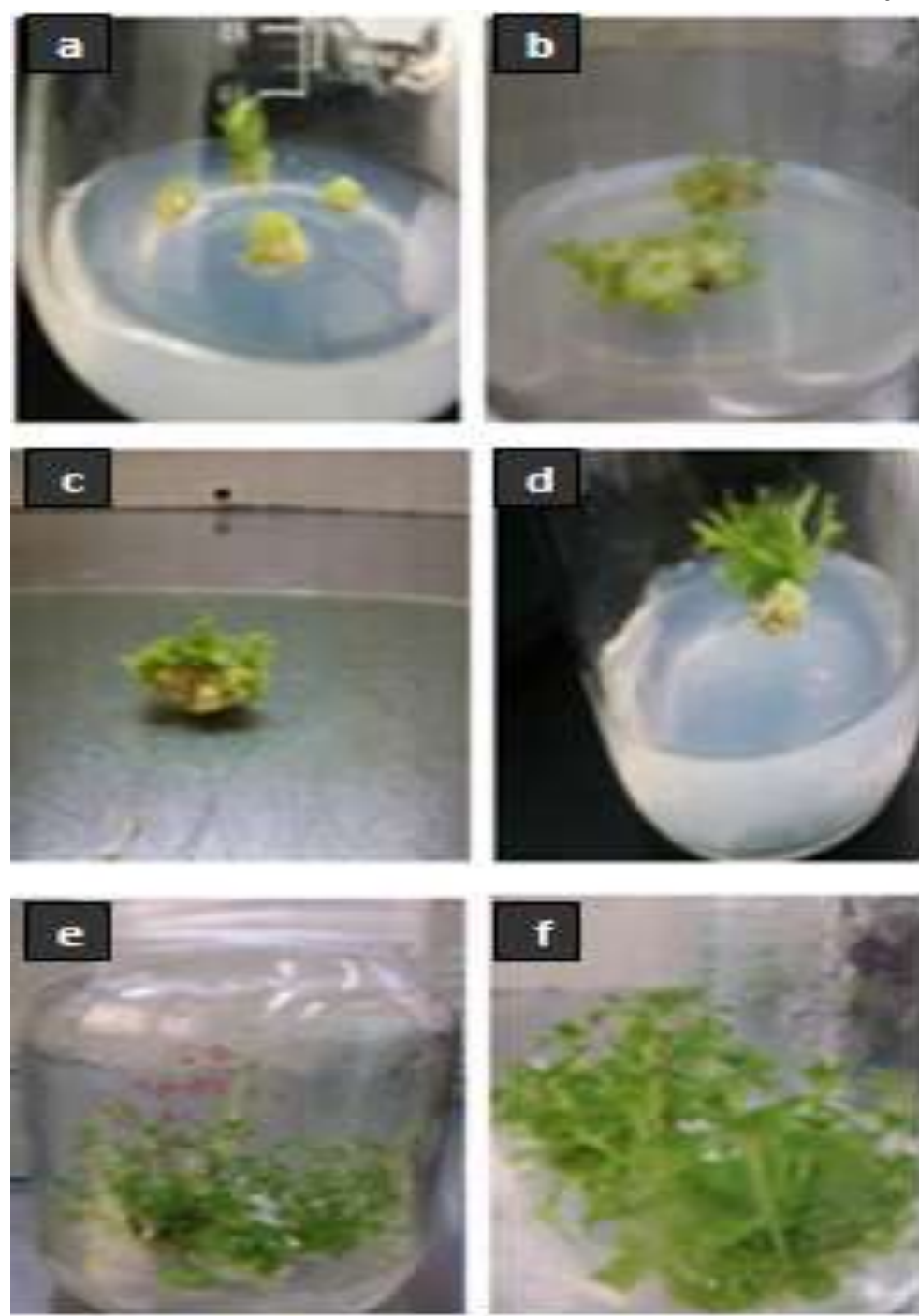

Figure 3. Shoot regeneration: on MS medium $+5 \mathrm{mg} / / \mathrm{l} \mathrm{BA}$ after 1)6days 2)10 days 3) 15 days 4) 20 days 4) 20 days 5)25 days 6$) 30$ days 
Table 2. Effect of different media on shoot formation of stevia rebaudiani (Bertoni)

\begin{tabular}{lccccc}
\hline Growth regulator & $\begin{array}{c}\text { Days } \\
\text { formation }\end{array}$ & $\begin{array}{c}\text { for } \\
\text { shoot }\end{array}$ & $\begin{array}{c}\text { Rate of shoot } \\
\text { formation }(\boldsymbol{\%})\end{array}$ & $\begin{array}{c}\text { Average length of the } \\
\text { longest shoot }(\mathbf{c m})\end{array}$ & $\begin{array}{c}\text { Number of } \\
\text { shoot per culture }\end{array}$ \\
\hline $\mathrm{MS}+5 \mathrm{mg} / \mathrm{l} \mathrm{BA}$ & $6.1 \mathrm{a}$ & $75 \mathrm{c}$ & $3.2 \mathrm{~b}$ & $32.6 \mathrm{c}$ \\
\hline $\mathrm{MS}+2 \mathrm{mg} / \mathrm{BA}$ & $12 \mathrm{bc}$ & $48 \mathrm{a}$ & $2.35 \mathrm{a}$ & $11.1 \mathrm{a}$ \\
\hline $\mathrm{MS}+1 \mathrm{mg} / \mathrm{l} \mathrm{BA}$ & $11.8 \mathrm{bc}$ & $46 \mathrm{a}$ & $1.99 \mathrm{a}$ & $11.2 \mathrm{a}$ \\
\hline $\mathrm{MS}+0.5 \mathrm{mg} / \mathrm{l} \mathrm{BA}$ & $11 \mathrm{~b}$ & $63 \mathrm{~b}$ & $3.66 \mathrm{~b}$ & $32.1 \mathrm{~b}$ \\
\hline $\mathrm{MS}+1 \mathrm{mg} / \mathrm{l}$ & $12.6 \mathrm{c}$ & $43 \mathrm{a}$ & $1.75 \mathrm{a}$ & $10.9 \mathrm{a}$ \\
$\mathrm{BA}+2 \mathrm{mg} / \mathrm{l} \mathrm{NAA}$ & & & & \\
\hline $\mathrm{MS}+1 \mathrm{mg} / \mathrm{l}$ & $12.6 \mathrm{c}$ & $59 \mathrm{~b}$ & $2.43 \mathrm{a}$ & $20.2 \mathrm{~b}$ \\
$\mathrm{BA}+2 \mathrm{mg} / \mathrm{l} \mathrm{Kin}$ & & & & \\
\hline
\end{tabular}

Means followed by different letters in the same column differ significantly at $\mathrm{p}=0.05$

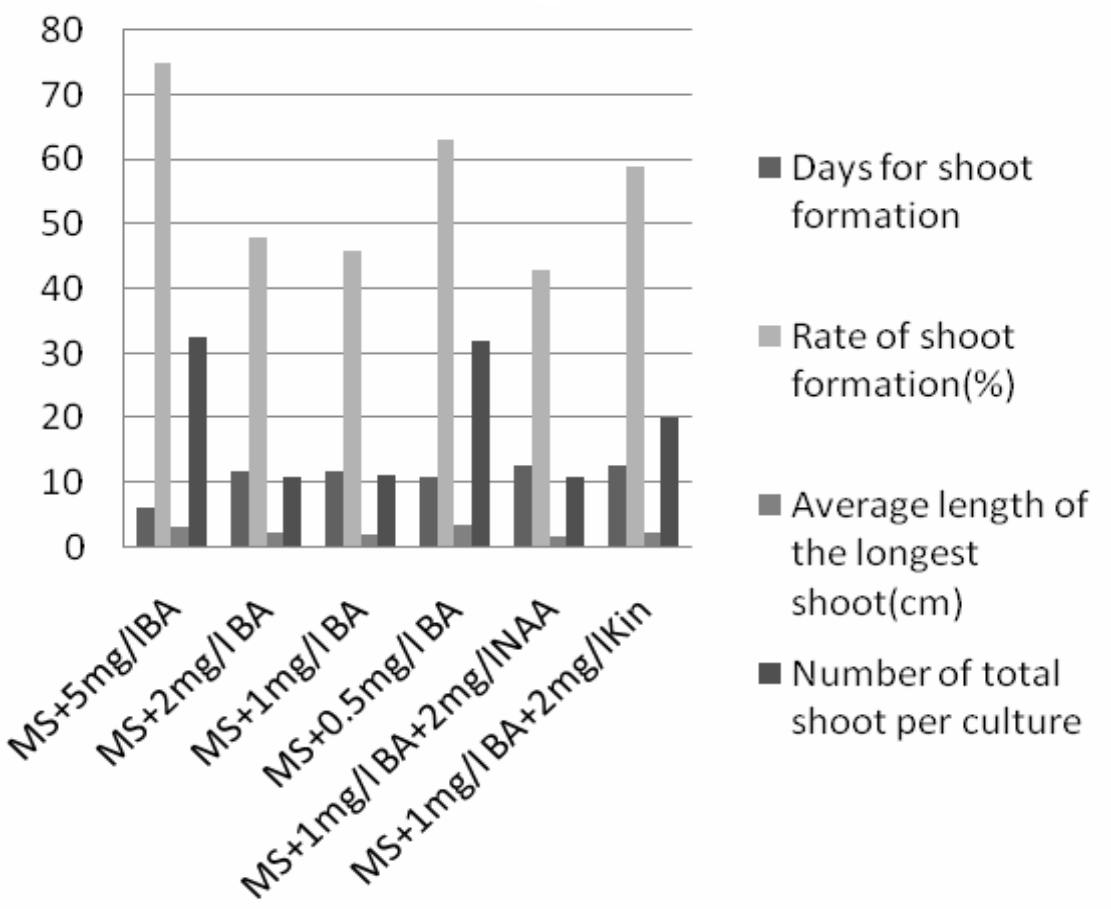

\section{Figure 4. Effect of different media on shoot formation of stevia rebaudiani (Bertoni)}

Denath (2008), Ahmed et al.(2007), Patil et al.(1996), Nepovin and Vanek (1998), Sikach(1998), Akita and Shigeoka(1994) and Sivaram and Mukundan(2003).reported that plant hormone is necessary for shooting, elongation and rooting. In most of cases BA was found to be essential for growth and multiple shoot formation of S.rebaudiana.

\section{3-Root induction}

The micro-cuttings of in vitro prolife rated shoots were implanted on MS media supplemented individually with IAA and IBA at concentrations of $0,1,2$ and $3 \mathrm{mg} / \mathrm{l}$ for root initiation. Among them, maximum percentage of root formation (56\%), number of root (6.1) and root length $(4.9 \mathrm{~cm})$ were observed on MS medium supplemented with 1mg/l IBA (Table 3 and figure 5).

The root induction was gradually decreased with the increasing of concentration of auxin types. Few numbers of roots formations were observed on free basal medium. Similar types of results were found by earlier workers for the same species (Sivaram and Mukundan,2003, Ahmed et al.2007; Mitra and pal, 2007).

These results are in similar with those obtained from Sivaram L, U Mukundan, 2003. Ahmed et al. 2007 and Mitra and Pal 2007. 
Table 3. Effect of different media on root induction

\begin{tabular}{lcccc}
\hline Means & $\begin{array}{c}\text { Days to initiated } \\
\text { roots }\end{array}$ & Rate of roots (\%) & $\begin{array}{c}\text { No. of roots per } \\
\text { plantlet }\end{array}$ & $\begin{array}{c}\text { Average length of } \\
\text { roots (cm) }\end{array}$ \\
\hline $\begin{array}{l}\text { Medium1 } \\
\text { MS0 }\end{array}$ & $19.3 \mathrm{~b}$ & $16 \mathrm{a}$ & $1.6 \mathrm{a}$ & $2.9 \mathrm{a}$ \\
\hline $\begin{array}{l}\text { Medium 2 } \\
\text { MS+1mg/l IBA }\end{array}$ & $18.7 \mathrm{~b}$ & $56 \mathrm{c}$ & $6.1 \mathrm{~d}$ & $4.94 \mathrm{~b}$ \\
\hline $\begin{array}{l}\text { Medium 3 } \\
\text { MS+2mg/l IBA }\end{array}$ & $15.7 \mathrm{a}$ & $28 \mathrm{~b}$ & $2.3 \mathrm{ab}$ & $2.81 \mathrm{a}$ \\
\hline $\begin{array}{l}\text { Medium 4 } \\
\text { MS+3mg/l IBA }\end{array}$ & $24.8 \mathrm{c}$ & $30 \mathrm{~b}$ & $3 \mathrm{bc}$ & $2.66 \mathrm{a}$ \\
\hline $\begin{array}{l}\text { Medium 5 } \\
\text { MS+1mg/l IAA }\end{array}$ & $17 \mathrm{ab}$ & $33 \mathrm{~b}$ & $3.2 \mathrm{bc}$ & $2.95 \mathrm{a}$ \\
\hline $\begin{array}{l}\text { Medium 6 } \\
\text { MS+2mg/l IAA }\end{array}$ & $15.8 \mathrm{a}$ & $29 \mathrm{~b}$ & $3.2 \mathrm{bc}$ \\
\hline $\begin{array}{l}\text { Medium 7 } \\
\text { MS+3mg/l IAA }\end{array}$ & $16.1 \mathrm{a}$ & $3.4 \mathrm{c}$ & $2.56 \mathrm{a}$ \\
\hline $\begin{array}{l}\text { Means followed by different letters in the same column differ significantly at } \mathrm{p}=0.05 \\
\end{array}$
\end{tabular}

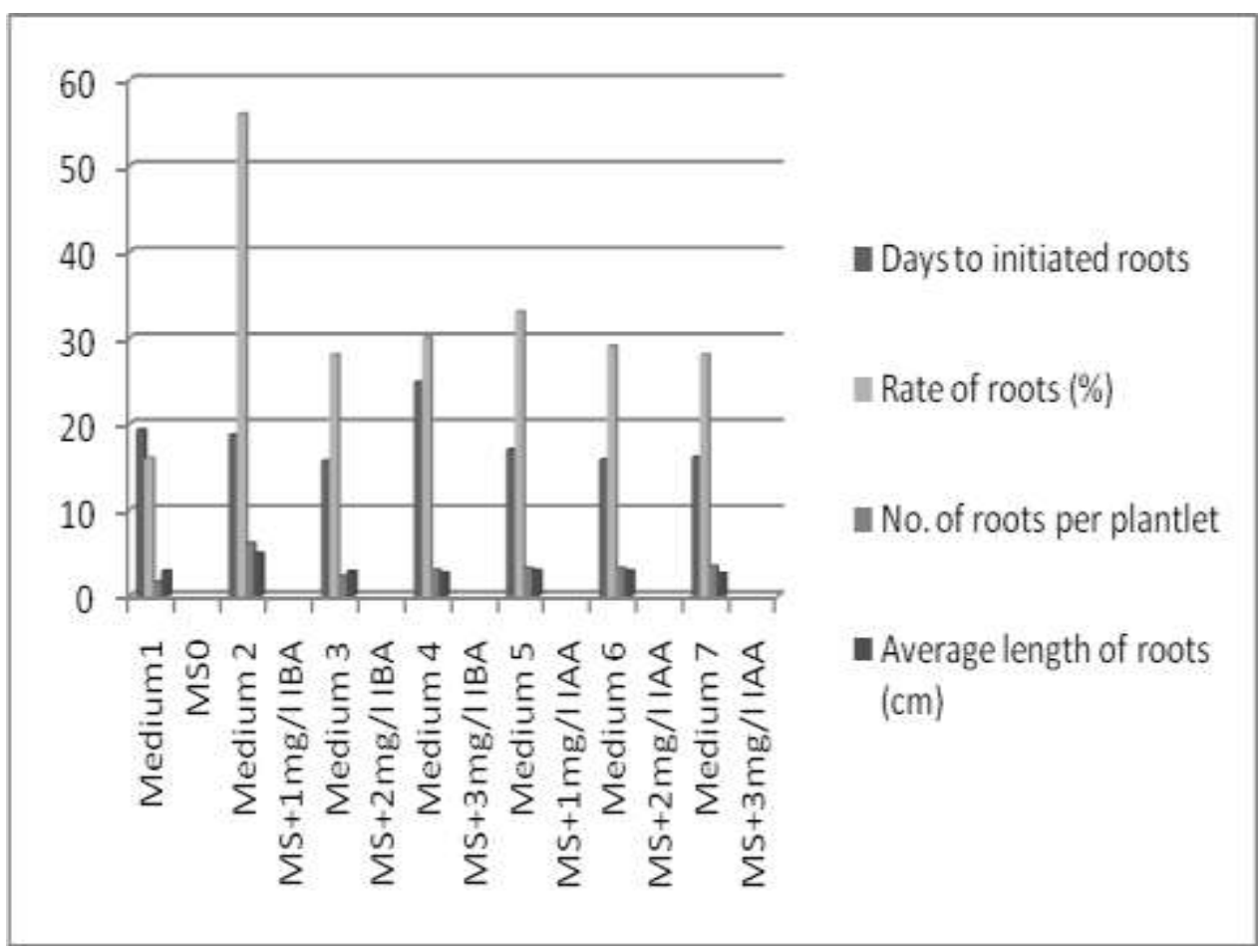

\section{Figure 5. representing the percentage of root regeneration, number of roots per shoot and average length of root of Stevia rebaudiana.}

\section{REFERENCES}

Alaam AI (2007). Sugar crops council: Future view. The Proceeding of Thirty-eight Annual Conference, Egyptian Sugar Expertese Society Hawamdia, Egypt.

Ahmed A, MN Huda, C Mandal, KA Alam, MSH. Reza, A Wadud, 2007. In vitro morphogenic response of different explant of Stevia (Stevia rebaudiana). Inter J Agri Res, 2: 1006-1013.
Amir ,A.,S. Irum, N. Shagufta, A. Shahid,2010. Biochemical investigation during different stages of in vito propagation of Stevia rebaudiana.Pak.J. Bot., 42(4): 2827-2837.

Akita, M., T. Shigeoka, Y. Koiumi and M.Kawamura, 1994. Mass propagation of shoots of stevia rebaudiana using large scale bioreactor.Plant Cell Rep.Japan., 13: 3-4,180183 . 
Chalapathi MV, S Thimmegowda, B Shivaraj, 1997. Natural non-calorie sweetener Stevia (Stevia rebaudiana Bertoni). A future crop of India. Crop Res Hisar, 14: 347-350.

Chawla, H.S. 2000. Introduction to Plant Biotechnology. Sci bub. Inc. Enfield NHUSA.

Debnal M (2008). Clonal propagation and antimicrobial activity of an endemic medicinal plant Stevia rebaudiana. J. Med. Plant Res. 2(2) 45-51.

Debnath, M., C.P. Malik and P.S.Bisen, 2006. Micropropagation: A tool for the production of high quality plant based medicines. Curr. Pharm. Botechnol., 7: 33-49.

Liu J, SFY Li, 1995. Separation and determination of Stevia sweeteners by capillary electrophoresis and high performance liquid chromatography. J Liquid Chromatography, 18: 1703-1719.

Mitra, A. and A. pal. 2007. In virto regeneration of Stevia rebaudiana (Bert) from nodal explants. J. Plant Biochem. Biotechnol. 16:59-62.

Murashige T, F Skoog, 1962. A revised medium for rapid growth and bioassay with tobacco tissue culture. Physiol Plant, 15: 473-497.

Nalawade, S.M., P.S. Abhay, L. Chen-Yue, K. Chao-Lin and T. Hsin-Sheng. 2002. Studies on tissue culture of Chinese medicinal plant resources in Taiwan and their sustainable utilization.Bot. Bull Acad. Sin., 44:79-98.

Nakamura S. and Tamura Y. (1985). Variation in the main glycoside of (Stevia rebaudiana), Jpn J. Agric., 29: 109116.

Nepovim A, T Vanek, 1998. In vitro propagation of Stevia rebaudiana plants using multiple shoot culture. Planta Medica, 64: 775-776.
Sairkar, P., M.K chandrvanh., N.P.Shukla, N.N. Mehrota. Mass production of an economically important medicinal plant Stevia rebaudiana using in vitro propagation techniques. Journal of Medicinal Plant Research Vol.3(4),PP.266-270,April, 2009.

Sivaram L, U Mukundan, 2003. In vitro culture studies on Stevia rebaudiana. In vitro Cellular and Developmental Biology Pl, 39: 520-523.

Sikach V, O (1998). Effect of nutrient media on physiological peculiarties of Stevia rebaudiana plants cultivated in vitro. Fiziologlya Bikhimiya Kulturnykh rastenii 30(4):294-299.

Sakaguchi M and Kan T (1982) Japanese researches on Stevia rebaudiana (Bert.) Bertoni and stevioside. Ci Cult. 34: 235-248.

Toyoda, K. and H. Matsui, 1997. Assessment of the carcinogenicity of stevioside in F344 rats. Food Chem.Toxicol., 35(6): 597-603.

Turhan, H.2004. Callus induction and growth in transgenic potato genotypes. Afri.J. of Biotech., 3: 375-378.

Patil V, Reddy PS, Ashwini KS, Purushotham MG, Prasad TG and Udayakumar M (1996) In Vitro multiplication of Stevia rebaudiana. Curr Sci. 70: 960.

Yamazaki, T. and H.E. Flores, 1991. Examination of stevial glucosides production by hairy root and shoot culture of Stevia rebaudiana. J. Natural Products., 45(4): 986-992.

Yoshida, S., 1986. Studies on the production of sweet substances in Stevia rebaudiana: I. Simple determination of sweet glucosides in stevia plant by thin layer chromatescanner and their accumulation patterns with plant growth.Jap. J. Crop Sci.,55(2): 189-195. 


\section{الملخص العربي}

\section{استخدام طريقة فعالة لإكثار نباتات الإستيفيا معملياً في مصر}

مروى مهدى غلاب، مجدى سعد صالح

ميراشيج واسكوج مع استخدام تركيزات مختلفة من منظمات النمو مثل تو فور دي والبنزيل ادنين والكينيتين.

وقد وجد أن بيئة ميراشيج وسكوج التي تحتوي على 1ملجم /لتمبر التر

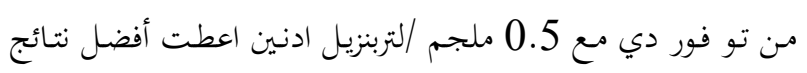

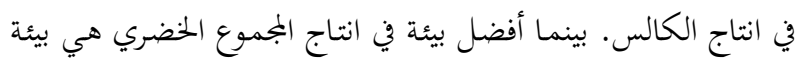

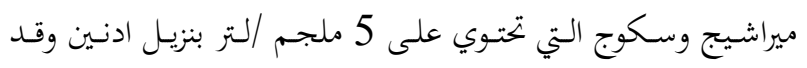

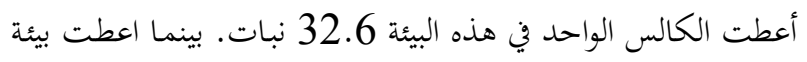

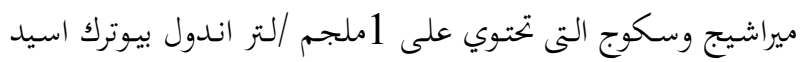

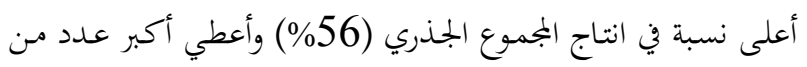
الجذور 6.1 جذور للنبات الواحد.
نبات الإستيفيا هو محلى طبيعى لايحتوى على سعرات حرارية مما

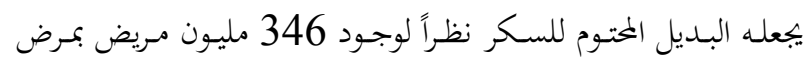

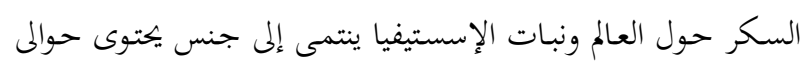
150 نوع من الأعشاب والشجيرات وقد نشأ في أرجواى فن أمريكا أجـرى هـذا البحتث في معمـل زراعـة الأنسجة بمحطـة البحـوث

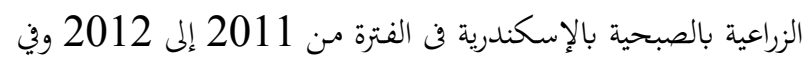

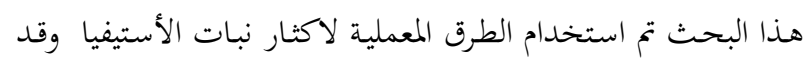
استخدمت الأوراق لانتاج الكالس وذلك باستخدام بيئة 